\title{
APPLICATION OF PHYTOREMEDIATION FOR HERBAL MEDICINE WASTE AND ITS UTILIZATION FOR PROTEIN PRODUCTION
}

\author{
Danny Soetrisnanto $^{1)}$, Marcelinus Christwardana ${ }^{2)}$ and Hadiyanto ${ }^{1,2 *}$ \\ ${ }^{1)}$ Department of Chemical Engineering, Diponegoro University, Semarang, Indonesia \\ ${ }^{2)}$ Center of Biomass and Renewable Energy, Laboratory of Bioprocess, Department of Chemical Engineering, \\ Diponegoro University, Semarang, Indonesia \\ Jl. Prof. Sudharto, SH-Tembalang, Semarang 50275, Phone : +62247460058 \\ ${ }^{*}$ Corresponding author: hady.hadiyanto@gmail.com
}

\begin{abstract}
Herbal industry in Indonesia is progressing very rapidly. Increasing number of herbal medicine industries lead to an increase of the waste which are normally processed in anaerobic ponds by using chemical and biological process. However this process are not economical feasible and therefore an alternative method by using natural resource is required. Phytoremediation is an environmental friendly method to reduce contaminant using aquatic plant. This method uses water plant to reduce COD and nutrients content in the waste. Since the waste still high content of nutrient, therefore it is potential for medium growth of algae Spirulina. This study was aimed to evaluate the use of various plant species (water hyacinth and lotus) in decreasing contaminant and to determine optimal nutrient composition of the growth media. The phytoremediation was performed in 3-8 days and height of liquid in the tank was maintained constant at $5 \mathrm{~cm}$. The effluent of first phytoremediation was transferred to second stage for cultivation of Spirulina with 15 days of cultivation time. The external nutrients were added each 2 days and the concentration of biomass was measured for its optical density. Spirulina grow well in herbal medicine waste that has been phytoremediation with lotus for 3 days and had a CNP ratio amounted to $57.790: 9.281: 1$ with a growth rate of $0.271 /$ day.
\end{abstract}

Keywords: biomass; herbal medicine waste; phytoremediation; spirulina; water plants

\begin{abstract}
Abstrak
APLIKASI FITOREMEDIASI UNTUK LIMBAH JAMU DAN PEMANFAATANNYA UNTUK PRODUKSI PROTEIN. Industri obat di Indonesia tumbuh sangat cepat. Pertumbuhan ini mengakibatkan meningkatnya limbah yang umumnya dilakukan dalam kolam anaerobik dengan menggunakan proses kimia dan biologi. Namun demikian, proses tersebut belum menunjukkan hasil ekonomis sehingga diperlukan metode lain yang relatif aman dan ekonomis. Salah satu cara yang dapat digunakan adalah phytoremediasi mengguanakn tanaman air untuk mengurangi kandungan COD dalam limbah dan nutrient. Dikarenakan limbah masih mengandung nutrient yang cukup banyak, maka limbah tersebut juga sangat potensial untuk digunakan sebagai medium mikroalga. Penelitian ini bertujuan untuk mengevaluasi penggunaan tanaman air (enceng gondok dan teratai) untuk mereduksi kontaminan dalam limbah obat jamu. Phytoremediasi dilakukan selama 4-8 hari dan tinggi cairan dalam reaktor dijaga pada $5 \mathrm{~cm}$. Keluaran dari phytoremediasi pertama menggunakan tanaman air digunakan sebagai medium di phytoremediasi menggunakan mikroalga Spirulina. Untuk mendapakan pertumbuhan yang optimum, maka ditambahakan juga nutrient dan menunjukkan bahwa Spirulina tumbuh dengan sangat baik dalam medium ini. Pertumbuhan terbaik diperoleh dari phytoremediasi menggunakan teratai selama 3 hari dan kecepatan pertumbuhan 0,271/hari dengan perbandingan $C: N: P=57,790: 9,28: 1$.
\end{abstract}

Kata kunci: biomasa; limbah jamu; phytoremediasi; spirulina; tanaman air 


\section{INTRODUCTION}

Indonesia is an agricultural country, where many plants grow very diverse. Among of them have function to cure various types of diseases in humans. For this purpose, then people use this plant into herbal medicine which made from a mixture of extracts of plants. Herbal medicine consists of two types, traditional herbal medicine and fitofarmaka or herbal medicine packs. Fitofarmaka is a traditional herbal medicine that uses natural ingredients but under modern processed (Lestari, 2007). Herbal medicine was commercialized in Indonesia since 1658 (Widiyanti, 2005).

Development of herbal medicine industries has proved that human consciousness to the use of natural ingredients for treating the disease. Synthetic drugs are mostly avoided due to its side effects. The main problem of herbal medicine industry is waste produced from its process. Most of herbal medicine waste contain phenol and its derivatives that have a serious effect to the environment (Kibret et al., 2000; Chung et al., 2003; Kumar et al., 1995). An herbal medicine industry normally produces wastewater with COD content of 200-20000 ppm and 9.8 ppm phenol.

Herbal medicine waste has a high COD content that must be processed before discharged into the river body. Usually herbal medicine waste is processed using biological and chemical process such as coagulation, sedimentation, aeration, and using activated sludge (Milasari and Ariyani, 2010). But these methods are not economically feasible. Phytoremediation is a remediation method by using green plants especially aquatic plants such as water hyacinth, lotus, etc and their associated microbiota, enzymes, water consumption, soil amendments, and agronomic techniques to remove, contain, or render harmless environmental contaminants such as heavy metal, pesticides and xenobiotics, organic compound, toxic aromatic pollutants, and acid mine drainage (Dordio and Carvalho, 2011; Suresh and Ravishankar, 2004; Newman and Reynolds, 2004; Singh and Jain, 2003; Archer and Caldwell, 2004). Due to nutrient content in the effluent, the waste can be further process as medium for microalgae growth. The consumption by microalgae is then considered as the second phytoremediation process.

The phytoremediation of herbal medicine waste had not been studied till today. The application of phytoremediation has been applied to palm oil mill effluent (POME) by using apu-apu (Pistia stratiotes) (Ahdia and Krismawati, 2012). In another study, water hyacinth has been used to remediate the active ingredient carbofuran phytoremediation (Karyadi and Istiono, 2008). In this research, phytoremediation was able to reduce the contaminants up $82.21 \%$. Microalgae require nutrient for their growth. The source of nutrient has been explored through the waste to cultivate Spirulina sp (Hadiyanto et al., 2012;
Suryajaya and Sari, 2012). In another research, Markou et al. (2012) cultivated Spirulina sp in Oliveoil Mill Waste Water (OMWW) medium which pretreated with sodium hypochlorite $(\mathrm{NaClO})$.

Since herbal waste load is enormous in Indoensia and has high conten of COD, N and $\mathrm{P}$, therefore, in this research phytoremediation were used as the chosen method. The nutrient in the phytoremediation by aqua plants were used as medium growth of microalgae. The aim of this research was to evaluate the use of various plant species that are water hyacinth (Eichhornia crssipes) and lotus (Nymphaea sp) in decreasing contaminant and to determine optimal nutrient composition of the algae growth media.

\section{MATERIAL AND METHODS}

\section{Herbal Medicine Waste}

Herbal medicine waste was collected from one of herbal medicine industries in Semarang. The waste then was filtered to separate impurities. The wastewater characteristic can be described in Table 1 .

\begin{tabular}{cc} 
Table 1. Characteristic Herbal Medicine Waste \\
\hline Parameter & Content \\
\hline pH & 6.75 \\
COD & $200 \mathrm{ppm}$ \\
BOD & $277 \mathrm{ppm}$ \\
TSS & $66 \mathrm{ppm}$ \\
Total N & $0.704 \mathrm{ppm}$ \\
Total P & $0.549 \mathrm{ppm}$ \\
Phenol & $0.39 \mathrm{ppm}$ \\
\hline
\end{tabular}

\section{Spirulina sp}

Spirulina sp was collected from Balai Besar Pengembangan Budidaya Air Payau (BBPBAP) Jepara and cultivated in Laboratory of Bioprocess, Diponegoro University. Spirulina $\mathrm{sp}$ was used as inoculums at $\mathrm{OD} 680=0.5$.

\section{Aquatic Plants}

Water hyacinth was collected from Rawapening Lake, Ambarawa. It was acclimated in $20 \%$ Herbal Medicine Waste medium for 5 days, while Lotus plant was collected from flower market in Surakarta and Semarang. It was acclimated in 20\% Herbal Medicine Waste medium for 5 days.

\section{First Stage of Phytoremediation}

The first remediation was purposed to reduce levels of COD and other nutrients by using phytoremediation under different aquatic plants (water hyacinth and lotus). Here, the height of liquid in the tank was also set at $5 \mathrm{~cm}$. Phytoremediation was done in different residence time (3, 6, 8 days). 


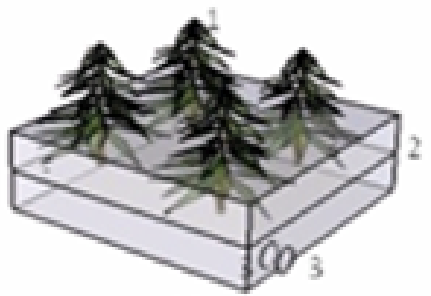

(1))
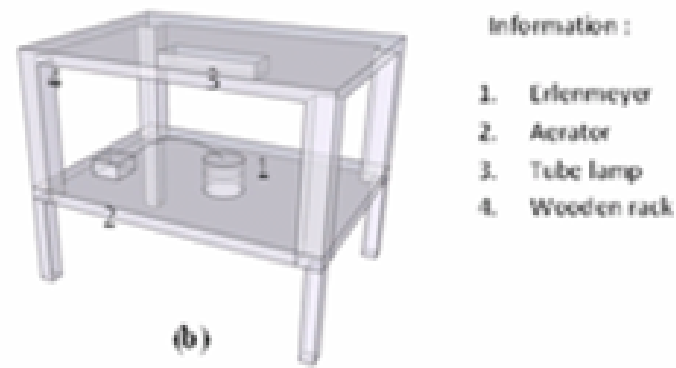

Figure 1. Experimental set up for phytoremediation

\section{Second Stage of Phytoremediation}

The second experiment of remediation was purposed to cultivate Spirulina sp using $80 \%$ herbal medicine waste that has been phytoremedated by different plants, retention time and using some nutrients (baking soda, TSP, and urea). The research was done in 15 days.

\section{Measurement}

Measurement of COD, N, and P concentration in herbal medicine waste done before and after phytoremediation according to set of residence time (day 3,6,8). Measurement of Optical Density (OD) was started from day 0 using spectrophotometer SP300 wave length $680 \mathrm{~nm}$. Medium was measured every day. Biomass was collected every two days from 2nd days until 10th days by using filter cloth. Wet Biomass was recorded as $90 \%$ moisture content (10\% Total Suspended Solid). Carbon, Nitrogen, and Phosphor was measured by Benfield and Randal method.

\section{RESULT AND DISCUSSION}

Evaluation from Type of Plants to Decrease COD and Nutrient

\section{COD reduction}

The initial concentration of COD was 200 ppm and it decreases to $55 \mathrm{ppm}(72 \%)$ after 8 days remediation using hyacinth, while $59 \mathrm{ppm}(70 \%)$ by using lotus (Figure 2). It is known that water hyacinth which covering $50 \%$ of total area could reduce suspended residues up to $75-85 \%$, while COD 5.52$76.83 \%$ (Rossiana et al., 2007). Water hyacinth shows the second highest of TSS and COD reduction after Cyperus papyrus (Irawanto, 2010).

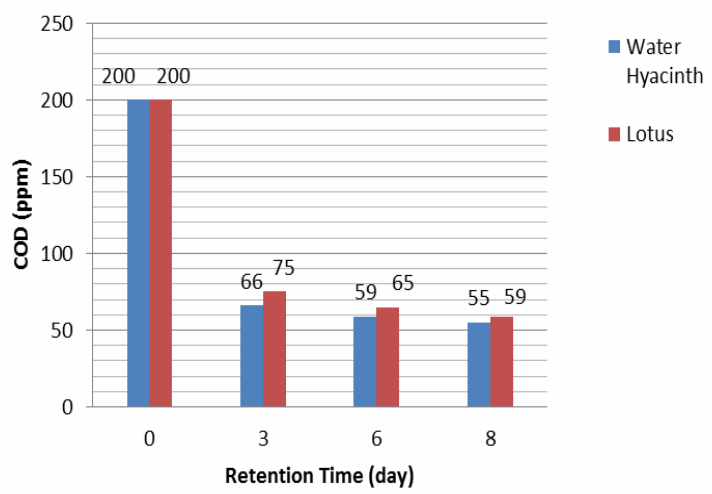

Figure 2. COD Reduction using Different Plants

\section{Nitrogen reduction}

Figure 3 shows the decrease of nitrogen content in the herbal medicine waste. The initial concentration of nitrogen is 0.704 ppm. After 8 days phytoremediation using water hyacinth, nitrogen concentration decrease to $0.222 \mathrm{ppm}(68 \%)$. While phytoremediation using lotus can reduce the concentration of nitrogen to $0.366 \mathrm{ppm}(48 \%)$.

Nitrogen is one of element needed for photosynthetic and it commonly consists of 3 forms such as organic nitrogen compounds, ammonium $\left(\mathrm{NH}^{+}\right)$ions, and nitrate $\left(\mathrm{NO}^{-}\right)$ions (Nasholm et al. 2008). The plant is able to reduce the concentration of ammonia by $81 \%$ within 10 days (Kutty et al., 2009). The enormous absorption of nitrogen from herbal medicine waste by using water hyacinth because of the availability of stomata (the stomata frequency on the upper epidermis was $2.83 \mathrm{~mm}^{2}$ and $3.32 \mathrm{~mm}^{2}$ on the lower epidermis) and its size $(4 \mu \mathrm{m} \times 4 \mu \mathrm{m})$ greater than lotus. Water hyacinth has a hollow and porous stem causing the process of photosynthesis not only takes place in the leaves but also in stems (Mahmood et al., 2005). This phenomena proves that water hyacinth need more nitrogen for photosynthesis than the lotus.

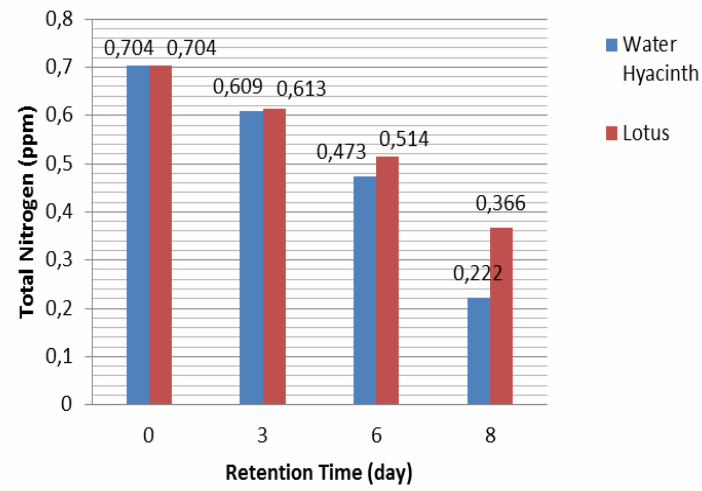

Figure 3. Total Nitrogen reduction using different aquatic plants 


\section{Phosporus reduction}

Phosphorus is also one of the essential nutrients for plant photosynthetic. Phosphorus contributes to the growth of the seeds, roots, flowers, and fruit. By improving the structure of root, the absorptive root would be better (Purwaningsih, 2009). The initial concentration of phosphorus in herbal medicine waste is $0.549 \mathrm{ppm}$ and after 8 days phytoremediation using water hyacinth, the concentration decrease to 0.3132 ppm. In other hand, phyotoremediation using lotus, phosphorous concentration decrease to $0.3144 \mathrm{ppm}$. Lotus also shows the capability to reduce the concentration of ammonia by $67 \%$ (Kutty et al., 2009).

Figure 4 shows the decreased of phosporus content in herbal medicine waste. Inline to absorption of nitrogen, phosphorus absorption using water hyacinth is higher than the lotus. It is because the water hyacinths have more stomata and its size is large. Water hyancinth also has a hollow stem and porous that support the absorption of minerals (especially phosphorus) more rapidly (Mahmood et al., 2005). In other hand, water hyacinth has also the ability to reduce phosphorus in pesticides (Xia and $\mathrm{Ma}$, 2006).

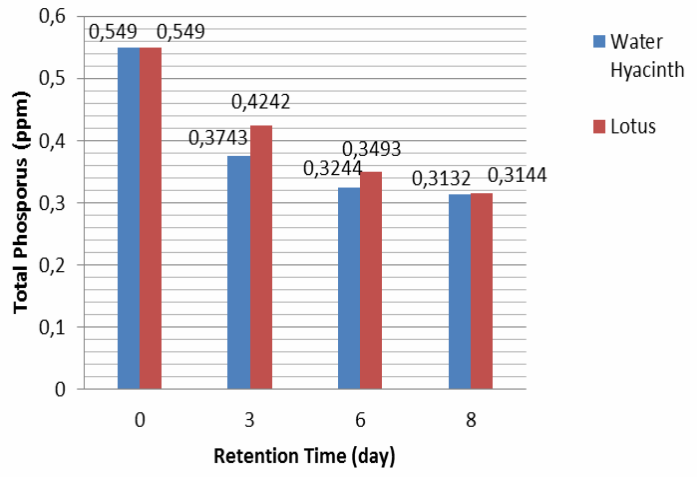

Figure 4. Total Phosporus reduction using different plants

\section{Growth Rate Analysis}

The remediated herbal medicine waste used as cultivation medium of alga Spirulina with the composition of $80 \%$. The addition of nutrients was the same i.e. $1000 \mathrm{ppm}$ baking soda, urea $60 \mathrm{ppm}$, and 10 ppm triple super phosphate. Control medium was medium I, using fresh water without any mixture of herbal medicine waste. Medium was measured using a spectrophotometer with an optical density OD680. The increase of OD in the medium can be seen in Figure 5. Optimum growth occurred in medium III (phytoremediation with lotus for 3 days), followed by medium II (water hyacinth-3 days), medium IV (water hyacinth-6 days), medium VI (water hyacinth-8 days), medium V (lotus- 6 days), and the last medium VII (lotus- 8 days). Growth rate and CNP ratio can be depicted in Table 2.

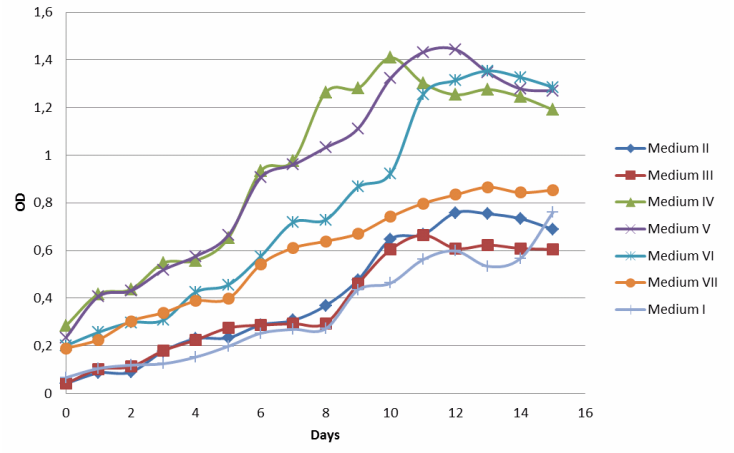

Figure 5. Increasing OD of Spirulina during cultivation using remediated medium

Table 2. Result of Growth Rate and CNP Ratio

\begin{tabular}{|c|c|c|c|c|}
\hline \multirow{2}{*}{ No } & \multicolumn{2}{|c|}{$\begin{array}{l}\text { Media (After } \\
\text { remediation) }\end{array}$} & \multirow{2}{*}{ CNP Ratio } & \multirow{2}{*}{$\begin{array}{l}\text { Growth } \\
\text { Rate/day }\end{array}$} \\
\hline & plant & $\begin{array}{c}\text { time } \\
\text { (days) }\end{array}$ & & \\
\hline I & - & - & $58.547: 10.586: 1$ & 0.197 \\
\hline II & $\begin{array}{c}\text { Water } \\
\text { hyacinth }\end{array}$ & 3 & $57.853: 9.436: 1$ & 0.181 \\
\hline III & Lotus & 3 & $57.790: 9.283: 1$ & 0.271 \\
\hline IV & $\begin{array}{c}\text { Water } \\
\text { hyacinth }\end{array}$ & 6 & $58.120: 9.558: 1$ & 0.154 \\
\hline $\mathrm{V}$ & Lotus & 6 & $58.235: 9.489: 1$ & 0.115 \\
\hline VI & $\begin{array}{c}\text { Water } \\
\text { hyacinth }\end{array}$ & 8 & $57.930: 9.526: 1$ & 0.136 \\
\hline VII & Lotus & 8 & $58.316: 9.562: 1$ & 0.097 \\
\hline
\end{tabular}

The recommended C:N:P ratio for algae growth was around 56:9:1 based on photosynthetic stoichiometry (Phang and Ong, 1988). In medium III, $\mathrm{C}: \mathrm{N}: \mathrm{P}$ ratio reached 57.790: 9.283: 1. The right content of the nutrients especially $\mathrm{N}$ and $\mathrm{P}$ influences on the growth rate of Spirulina (Hadiyanto et al., 2012). Nitrogen is used to help produce proteins when amount of carbohydrates are limited (Goksan et al., 2007). The main function of Carbon is as builder substances for Spirulina and only used a little to the process of photosynthesis. Excess of Carbon will not affect the rate of growth of Spirulina because it is an inhibition. While excess of minerals such as $\mathrm{N}$ and $\mathrm{P}$ will be converted as toxic and affect the growth rate of Spirulina (Mun et al., 1989). The other factors that affect the growth rate of Spirulina is the adaptation time. Spirulina in medium IV had a higher growth rate than the medium $\mathrm{V}$, while the content of $\mathrm{N}$ in medium IV is more than the medium V. This shows that time adaptation of Spirulina in medium IV is better than Spirulina in the medium V (Hadiyanto et al., 2012).

\section{CONCLUSION}

From the result of experiment, it can be concluded that phytoremediation by using Water Hyacinth is more effective than using lotus for contaminant reduction. In the second stage of phytoremediation, microalgae Spirulina can grow well 
in effluent of the first phytoremediation which has been remediated by lotus and 3 days of retention time.

\section{ACKNOWLEDGEMENTS}

This work supported by Center of Biomass and Renewable Energy (C-BIORE) Chemical Engineering Diponegoro University through Penelitian Unggulan DIPA FT UNDIP 2012.

\section{REFERENCES}

Ahdia, R. and Krismawati, R., (2012), Pengolahan Efluen Pond Fakultatif Anaerobik IPAL Industri Kelapa Sawit secara Fakultatif AnaerobikFitoremediasi sebagai Pre-Treatment Media Tumbuh Algae, Diponegoro University.

Archer, M.J.G and Caldwell, R.A., (2004), Response of Six Australian Plant Species to Heavy Metal Contamination at An Abandoned Mine Site, Water Air Soil Poll., 157(1-4), pp. 257-267.

Chung, Y.S., Kim, H.S., Jugder, D., Natsagdorj, L., and Chen, S.J., (2003), On Sand and Duststorms and Associated Significant Dustfall Observed in ChongjuChongwon, Korea During 1997-2000, Water, Air, and Soil Pollution, Focus, 3(2), pp. 5-19.

Dordio, A. and Carvalho, A.J.P., (2011), Phytoremediation : an Option for Removal of Organic Xenobiotics from Water, Handbook of Phytoremediation, ISBN: 978-1-61728-753-4, pp. 5192.

Goksan, T., Zekeriyaoglu, A., and Ak, I., (2007), The Growth of Spirulina platensis in Different Culture Systems Under Greenhouse Condition, Turk. J. Biol., 31, pp. 47-52.

Hadiyanto, Nur, M.M.A., and Harjanto, G.D., (2012), Enhancement of Biomass Production from Spirulina sp Cultivated in POME Medium, Proceeding of International Conference on Chemical and Material Engineering 2012, ISBN: 978-602-097-281-7.

Irawanto, R., (2010), Fitoremidiasi Lingkungan dalam Taman Bali, Local Wisdom, 2(4), hal. 29-35.

Karyadi and Istiono, E., (2008), Fitoremediasi Bahan Aktif Carbofuran Menggunakan Eceng Gondok (Eichornia crassipes (Mart) Solms), Agromedia, 2, hal. 63-72.

Kibret, M., Somitsch, W., and Robra, K.H., (2000), Characterization of Phenol Degrading Mixed Population by Enzyme Assay, Wat. Res., 34(4), pp. 1127-1134.

Kumar, P.B.A.N., Dushenkov, V., Motto, H., and Raskin, I., (1995), The Use of Plants to Remove Heavy Metals from Soils, Environmental Science and Technology, 29(5), pp. 1232-1238.
Kutty, S.R.M., Ngatenah, S.N.I., Isa, M.H., and Malakahmad, A., (2009), Nutrients Removal from Municipal Wastewater Treatment Plant Effluent using Eichhornia Crassipes, World Academy of Science, Engineering and Technology, 36, pp. 828-833.

Lestari, E.D., (2007), Analisis Daya Saing, Strategi Dan Prospek Industri Jamu Di Indonesia, Bogor Agricultural Institute.

Mahmood, Q., Zheng, P., Siddiqi, M.R., ul Islam, E., Azim, M.R., and Hayat, Y., (2005), Anatomical Studies on Water Hyacinth (Eichhornia Crassipes (Mart.) Solms) Under the Influence of Textile Wastewater, J. Zhejiang Univ. Sci. B., 6(10), pp. 991998.

Markou, G., Chatzipavlidis, I., and Georgakakis, D., (2012), Cultivation of Arthrospira (Spirulina) Platensis in Olive-Oil Mill Wastewater Treated with Sodium Hypochlorite, Bioresource Technology, 112, pp. 234-241.

Milasari, N.I and Ariyani, S.B., (2010), Pengolahan Limbah Cair Kadar COD dan Fenol Tinggi dengan Proses Anaerob dan Pengaruh Mikronutrient Cu : Kasus Limbah Industri Jamu Tradisional, Diponegoro University.

Mun, M.D., Osborne, L.L., and Wiley, M.J., (1989), Factors Influencing Periphyton Growth in Agricultural Streams of Central Illinois, Hydrobiologia, 174, pp. 89-97.

Nasholm, T., Kielland, K., and Geneteg, U., (2008), Uptake of Organic nitrogen by Plants, Tansley Review, New Phytologist, 182, pp. 31-48.

Newman, L.A and Reynolds, C.M., (2004), Phytodegradation of Organic Compounds, Curr. Opin. Biotechnol., 15, pp. 225-230.

Phang, S.M. and Ong, K.C., (1988), Algal Biomass Production in Digested Palm Oil Mill Effluent, Biol. Wastes, 25, pp. 177-191.

Purwaningsih, I.S., (2009), Pengaruh Penambahan Nutrisi Terhadap Efektifitas Fitoremediasi Menggunakan Tanaman Enceng Gondok (Eichhornia crassipes) Terhadap Limbah Orto-Klorofenol, Jurnal Rekayasa Proses, 3(1), hal. 5-9.

Rossiana, N., Supriatun, T., and Dhahiyat, Y., (2007), Fitoremediasi Limbah Cair dengan Eceng gondok (Eichornia carssipes (Mart)Solms dan Limbah Padat Industri Minyak Bumi dengan Sengon (Paraserianthes falcataria L. Nielson) Bermikroba, Padjadjaran University.

Singh, O.V. and Jain, R.K., (2003), Phytoremediation of Toxic Aromatic Pollutants from Soil, Appl. Microbiol. Biot., 63, pp. 128-135. 
Suresh, B. and Ravishankar, G.A., (2004), Phytoremediation - A Novel and Promising Approach for Environmental Clean-up., Crit. Rev. Biotechnol, 24, pp. 97-124.

Suryajaya, I.M.A. and Sari, F.Y.A., (2012), Kultivasi Mikroalga Spirulina platensis dalam Media POME dengan Variasi Konsentrasi POME dan Komposisi Jumlah Nutrien, Diponegoro University.
Widiyanti, H., (2005), Sejarah perkembangan Industri Jamu Tradisional dan Pengaruhnya Terhadap Kehidupan Sosial Ekonomi Masyarakat Gentasari Kecamatan Kroya Kabupaten Cilacap Tahun 19902002, Semarang State University.

Xia, H. and Ma, X., (2006), Phytoremediation of Ethion by Water Hyacinth from Water, Bioresource Technology, 97, pp. 1050-1054. 